\title{
Security Aspects of Gated Community Housing and the Concept of Safe Townships*
}

\author{
Zurinah Binti Tahir, Khadijah Binti Hussin \\ Universiti Teknologi Malaysia, Skudai Johor, Malaysia
}

\begin{abstract}
Crime is often associated with urban development as urban areas tend to be at greater risk security-wise as compared with other areas. This is the reality of an increasing population crowding into the cities, and fomenting crime in the process. The physical design of the environment also contributes to the escalating crime rate, resulting in fear and anxiety among the residents. The "Safe Township" concept is an approach to resolving the issue of security in urban areas. It is an agenda within the concept of liveable cities that focuses principally on the problems of urban security. The development of properties within the concept of Gated Community housing is considered a step towards protecting residents in a residential area. The development of fenced Gated Community housing equipped with full-time security facilities is among the strategies in implementing the concept of the Safe Township. This paper discusses the security features in the Gated Community housing development as measures to combat crime in line with the implementation of the Safe Township concept. This study adopts an investigative methodology that combines theory with case studies. The compilation of data was made through literature search, interviews with representatives from the Town Planning Department and data were also collected through observations of Gated Community housing schemes in Johor Bahru.
\end{abstract}

Keywords: crime, gated community, safe township concept, safety, security

\section{Safe Township Concept}

The Safe Township concept in crime prevention programmes places much emphasis on the security and safety aspects of daily life. Urban safety issues involve stakeholders such as police, local authorities, residents and local NGOs. Not only are the crime rate statistics the main indicator for measuring the safety level of a town, but they can also serve to reduce anxiety or fear of crime among the residents.

In Malaysia, the concept of the Safe Township has been proposed by the Malaysian Crime Prevention

\footnotetext{
* Acknowledgements: Research on the security features in the gated community housing development is supported by Zamalah, Institutional Scholarship provided by University of Technology Malaysia and My Ph.D. Scholarship, Ministry of Higher Education of Malaysia. The author would like to thank the anonymous reviewers for useful comments and suggestions on this paper.

Zurinah Binti Tahir, Ph.D. candidate of Land Administration and Development, Department of Land Administration and Development, Faculty of Geoinformation and Real Estate, Universiti Teknologi Malaysia.

Khadijah Binti Hussin, Ph.D. in Law (Department Law), Department of Land Administration and Development, Faculty of Geoinformation and Real Estate, Universiti Teknologi Malaysia.

Correspondence concerning this article should be addressed to Zurinah Binti Tahir, Department of Land Administration and Development, Faculty of Geoinformation and Real Estate, Universiti Teknologi Malaysia, Skudai Johor 81310, Malaysia. E-mail: tahirzurinah@yahoo.com.
} 
Foundation (MCPF) as early as 1998 when Bangsar was selected as the pioneer in its implementation with the installation of close circuit television (CCTV) in the commercial areas of Bangsar Baru. The move achieved its aim as the incidence of crime reportedly declined 12 percent. The scheme was subsequently extended to several other areas in the Klang Valley and to other major cities all over the country (Ministry of Housing and Local Government, Malaysia, 2010).

A Safe Township is created along the principles of sustainable development, and focuses on the "people-centered sustainable development" model. The planning of a safe housing development involves a tripartite relationship between the developer, residents and the environment. Safe townships not only safeguard the economy, but they also help to ensure unity and social well-being (Jamaludin Mustaffa, 2007). This seminar paper discusses the security features found in the Gated Community housing development that are adopted to meet the criteria and principles of the Safe Township concept.

\section{Quality of Life and the Concept of a Safe Township}

Arising from the Malaysia Quality of Life Report (1999), the concept of the quality of life entails changes in society and the social system from an arguably unsatisfactory state to an improved situation. Accordingly, the quality of life encompasses not only economic development, but also other aspects such as social, psychological, cultural, political and environmental development. The quality of life in Malaysia embraces self-development, a healthy lifestyle, access to knowledge and the freedom to acquire it. It may also be regarded as a standard of living that exceeds the basic individual needs. The quality of life should fulfil the psychological need for social well-being matching the national aspiration. Maslow (1954) stated that quality life will be achieved when all needs of life are met.

Ferran (1990) suggested that the quality of life encompassed various concepts and issues that could be divided into five categories. These categories focussed on: (1) the ability to live a normal life; (2) happiness and contentment; (3) goal achievement; (4) ability to strive for a useful and meaningful social life; and (5) physical and mental capacity. The study of Grant et al. (1994) also stressed the necessity for various definitions of a quality life. This study established that a quality life arose from four dimensions or domains, namely, (1) physical well-being; (2) psychological well-being; (3) social well-being; and (4) spiritual well-being.

The social quality of life reflects the development of a country. The people have the right to living a quality life. The understanding of the concept and meaning of a quality society may vary according to various indices of a country. While a variety of meanings and interpretations exist, the quality of life, according to the present discussion, refers essentially to the basic minimum needs that should be available to the resident of a township (Wan Rozali, 2002). These basic needs are important in the acquisition of a quality life and sustainable development. Wheeler (1998) contended that the issues of basic needs that were often raised in the context of sustainable development were no longer a primary goal in the attainment of quality life. Ainur Zaireeen (2006) in her study discussed the issues of sustainable development, and the issues that posed the main questions as to how a township that was greener, safer and more comfortable might be achieved. How might the landscape of a township be shaped to achieve its own identity while protecting its community? All these issues pose a challenge to making a township or city liveable in the long run, in keeping with the concept of liveable cities. 


\section{Strategy for the Development of Gated Community Housing in the Context of a Safe Township}

In recent times, walled communities established as "gated and guarded communities" have become increasingly popular. Besides high rise condominiums, this concept is being gradually extended to "landed gated communities" in many places, including the United States. Gated Communiites have since emerged in Europe, from Portugal to Poland and Scandinavia (Norazmin, 2007).

As the concept of a housing scheme behind walls is relatively new in Malaysia, there are no statistics to show the actual number of gated communities in Malaysia. Nevertheless, the recent expansion of gated community housing in Malaysia has been notable, especially in the large cities such as Kuala Lumpur, Penang, Johor Bahru and other areas that command premium property prices.

In Kuala Lumpur, there are Gated Community housing projects such as Sierramas in Sungei Buloh, Kajang Country Homes in Kajang, Tropicana and Damansara Indah Resort Homes in Damansara, Subang Villa in Subang Jaya and The Mines in Serdang (Azlinor, 2005). In Johor Bahru, similar housing schemes include Leisure Farm Gelang Patah in Gelang Patah, Taman Bukit Indah in Pulai, Sri Pulai Utama in Skudai and Sierra Perdana in Tebrau.

The Gated Community concept has found a place in the heart of property buyers, especially in the urban areas. A lot of them prefer not only to have their houses located within the Gated Community, but they also want their recreational spaces, and playgrounds to be protected behind secure walls, and the entrances and exits of the housing area to be controlled by security guards.

The living environment, whether promoted as "urban living or as natural scenery and environment", has a powerful draw when depicted as a Gated Community lifestyle, especially one that connotes a prestigeous community or a recreational lifestyle (Ismar, 2007). These reasons notwithstanding, the main attaction of the Gated Community concept is the aspect of security, landscaped surroundings and the variety of facilities that are available to residents (Clarke, 2004).

The Gated Community lifestyle that has won so many admirers is essentially a housing development protected by fences or walls. This housing concept restricts access of the public into the housing area, and it reflects a choice of living, identity and status of the resident. It is arguably also a response to the increasing crime rates in urban areas. Hence, this seminar paper discusses the concept of Gated Communities that offer various security features that might provide an answer to the current spate of crimes, and that fits in well with the Safe Township concept. The studies that will be undertaken in several selected locations such as Johor Bahru City can serve as case studies that focus on the security aspects of community security.

\section{Concept of Security in a Safe Township}

The issue of personal safety is an aspect of the national agenda that is very important and is, accordingly, given due emphasis on the 10th Malaysia Plan. Various strategies have been drawn up to shape a living environment and community that is safer, and therefore more attractive. The government is aware that the effect of crime has not only affected society adversely, it is also endangering the national economy. In view of this, the government has initiated various programmes towards reducing the crime rate and creating a living environment that is safer and more pleasant.

The Hierarchy Theory of Maslow declares that the element of security as the second requirement which is 
sought in life (see Figure 1). The importance of security in life attains prominence once an individual has fulfilled his or her physiological needs, such as shelter, food, clothing and so forth (Maslow, 1954).

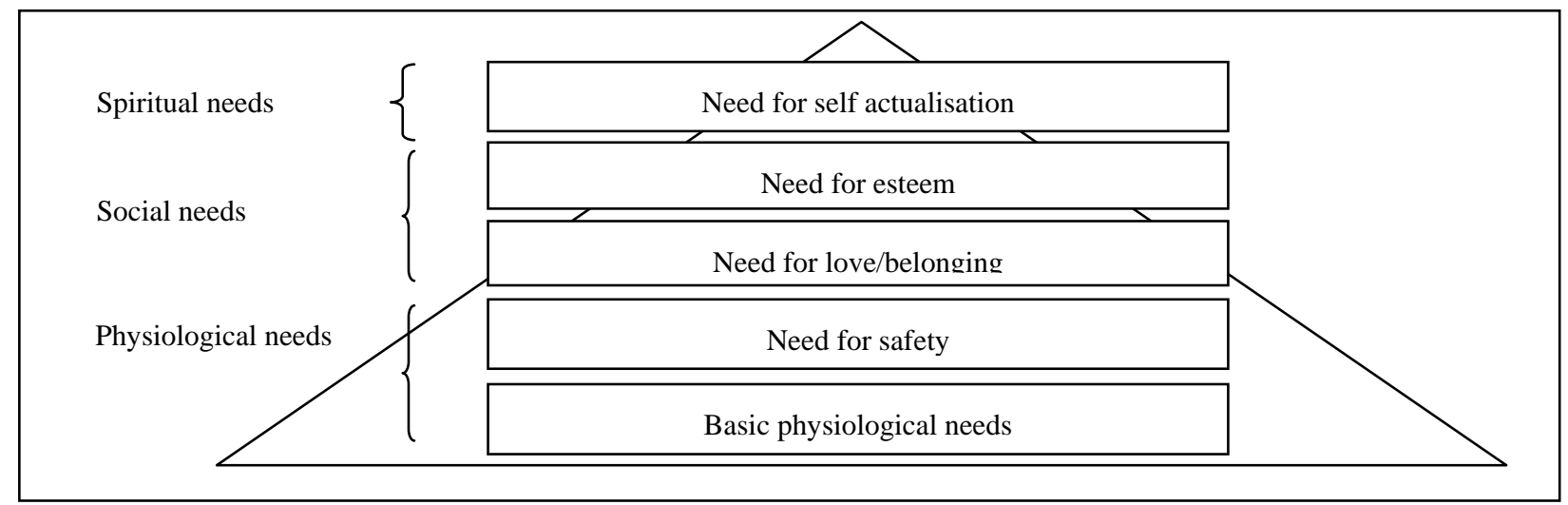

Figure 1. Maslow's Hierarchy of Needs Theory showing the more basic needs at the bottom.

\section{Steps in Crime Prevention in the Safe Township Programme}

There are 23 steps in the three strategies of the Safe Township Programme for implementation by the local authorities, departments and technical agencies, and the public (see Table 1). The steps are as follows.

Table 1

Steps in Crime Prevention in the Safe Township Program

\begin{tabular}{|c|c|}
\hline Strategy & Steps for crime prevention \\
\hline $\begin{array}{l}\text { Strategy 1: Designing the physical } \\
\text { environment }\end{array}$ & $\begin{array}{l}\text { Step1-Separate pedestrian walkways from motorways } \\
\text { Step2-Prepare bollards } \\
\text { Step3-Control plants used in landscaping around pedestrian walkways } \\
\text { Step4-Research in crime prevention through environmental Designing } \\
\text { Step5-Sharing of crime information through GIS-based mapping } \\
\text { Step6-Review of guidelines for housing layout }\end{array}$ \\
\hline $\begin{array}{l}\text { Strategy 2: Strengthening the } \\
\text { target area (target hardening) }\end{array}$ & $\begin{array}{l}\text { Step7-Set up police pondok } \\
\text { Step8-Install crime reminder notice boards } \\
\text { Step9-Install safety mirrors } \\
\text { Step10-Install security alarm } \\
\text { Step11-Tidy up overgrown shrubbery and areas hidden from view } \\
\text { Step12-Provide locked motorcycle park } \\
\text { Step13-Install closed circuit television (CCTV) } \\
\text { Step14-Install lighting along five-foot ways (walkways) of commercial areas } \\
\text { Step15-Ensure walkways are not hidden from view of passersby } \\
\text { Step16-Brighten up areas where people congregate } \\
\text { Step17-Disallow hawkers and vehicle parking along five-foot ways and pedestrian walkways } \\
\text { Step18-Establish various trading activities } \\
\text { Step19-Engage commercial security service }\end{array}$ \\
\hline $\begin{array}{l}\text { Strategy 3: Implement social/ } \\
\text { community activities and } \\
\text { public awareness learning }\end{array}$ & $\begin{array}{l}\text { Step20-Facilitate learning } \\
\text { Step21-Install lighting in sidelanes and in the front and rear of houses } \\
\text { Step22-Prepare a community crime handbook } \\
\text { Step23-Increase police patrol in housing areas }\end{array}$ \\
\hline
\end{tabular}

Note. Source: Department of Town and Country Planning, Malaysia, 2010.

\section{Conceptual Framework}

\section{Theory of Defensible Space}

The Theory of Defensible Space emphasizes two basic social behaviours, viz., territoriality and natural surveillance (see Figure 2). Newman (1972) felt that both these types of social behaviour were interconnected. 
Territoriality is essentially a sense of possession or a sense of belonging felt by an individual in relation to his living space.

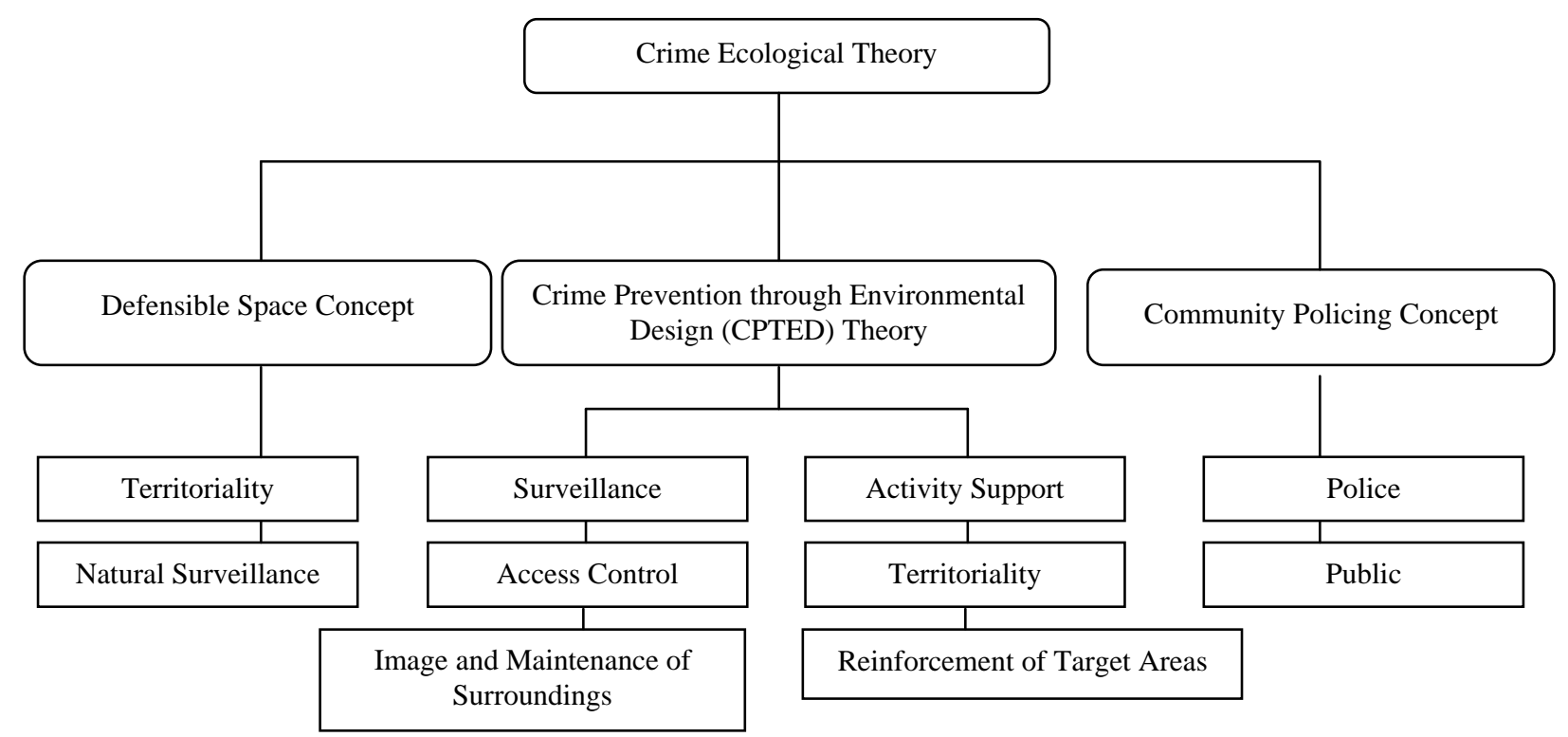

Figure 2. Crime ecological theory.

The image that the environmental design projects have an important influence on molding a feeling of belonging. In this regard, Lynch (1960) recognizes the influence of image and surroundings in shaping criminal behaviour and the fear of crime. This is because such an image embodies the living surroundings that the residents come into contact with. A neighbourhood equipped with various amenities encourages interaction between members in the community. According to Wilson and Kelling (1982), interaction between community members is crucial to fostering the spirit of neighbourliness. Such feelings of neighbourliness indirectly strengthen the sense of belonging and fellowship among one another.

Through territoriality, residents of a community see themselves as owners of the residential area and they spontaneously develop a feeling of responsibility towards its upkeep and management. Such sentiments are not limited to the house compound; they extend to the surrounding areas as well. This is in agreement with Newman (1972) who notes that an area is under greater threat from crime if the feeling of belonging and spirit of neighbourliness in the community are lacking. If the bonds between neighbours are strong, residents tend to be more aware of the presence of intruders in the neighbourhood. Such natural vigilance draws upon the ability of residents to recognize the opportunities to curb crime while carrying on with their daily activities.

\section{Crime Prevention Through Environmental Design (CPTED)}

The concept and principles of Crime Prevention Through Environmental Design (CPTED) should be applied from the early stages of design planning and housing planning for all new developmental areas. Nevertheless, the concept of CPTED may still be applied to established areas that are lacking in security, and are vulnerable to crime. In his model to combat crime through the Crime Prevention Through Environmental Design (CPTED), Jeffrey (1972) expounds on the theory that developments and modifications carried out in the physical surroundings to strengthen security would render it easier to control. The CPTED crime prevention model 
comprises six components, viz., surveillance, access control, image and maintenance of surroundings, reinforcement of target areas, activity support, and territoriality (see Figure 3).

CPTED basically retains the functional aspects of territoriality, image and surveillance that feature in the Theory of the Defensible Space. Nevertheless, the components of security proposed by Jeffrey are not limited to natural surveillance, but also to formal surveillance and mechanical surveillance. Formal surveillance refers to the appointment of security officers and the implementation of security patrols. Mechanical surveillance involves security equipment such as Closed Circuit Television (CCTV) and lighting. Where the perception of a locality is concerned, Jeffry adds that its maintenance is important to the promotion of quality image of the area. Maintenance should be extended to secluded areas that could otherwise become a haven for criminals. If such maintenance is undertaken continuously, the physical surroundings function effectively to engender social communication within a cohesive society and, in the process, promote natural surveillance (Cozens \& Plimmer, 2000).

This model is further strengthened by the presence of other components such as access control, activity support and the reinforcement of selected areas. This theory maintains that access control is very important to regulate entry to, and exit from the area. With such control in place, intruders more easily detected. Access control can be carried out using mechanical security equipment such as barriers and locks, or by employing a security force.

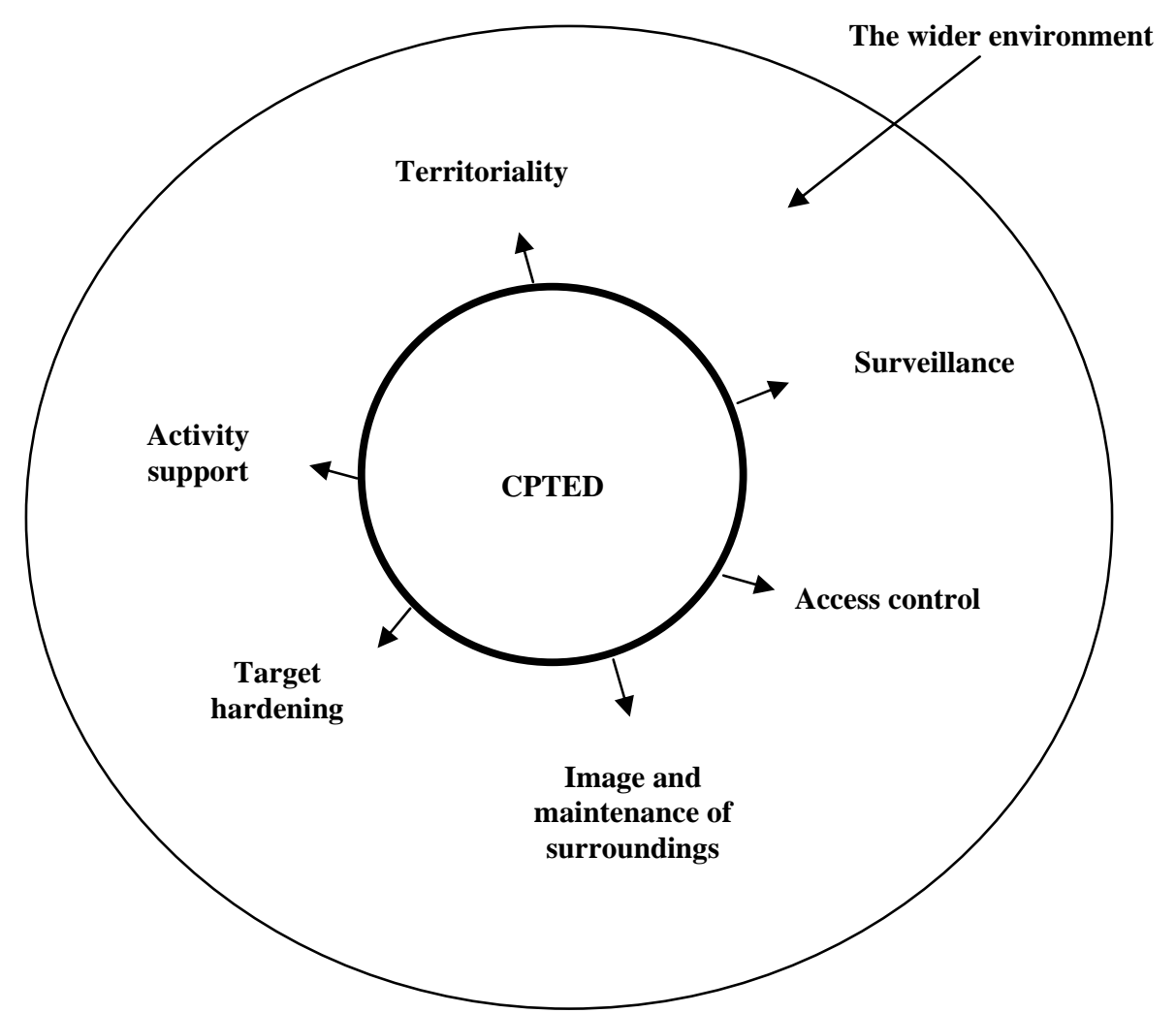

Figure 3. The CPTED crime prevention model. Source: Paul Michael (2006).

\section{Community Policing Concept}

The Community Policing Concept, which is a part of the Polis Diraja Malaysia (PDRM) Five Year Strategic 
Plan for 2007-2011, has helped to reduce the crime rate in several parts of Malaysia. This concept raises the level of service of the police force to the community, as well as strengthens the rapport between police and the public (see Figure 2). The Community Policing Concept was undertaken in three phases. The first phase involved the police contingents from Kuala Lumpur, Selangor, Penang and Johor. The second phase involved contingents from all the states, whereas the third phase involved all contingents and districts in each state. Among the areas that have successfully implemented the concept is Taman Seri Maharani, Muar and Taman Tan Sri Yaakub in Johor, Taman Wangsa Maju in Sentul, Kuala Lumpur, and Taman Ocean in the Timur Laut district of Penang. Taman Seri Maharani can be regarded as a model concept, with several programmes having been implemented with the active participation of residents of the housing estate. The zero crime index is a clear indicator of its effectiveness. Among the countries that have adopted this concept are the United Kingdom, the United States, Hong Kong, Australia and Singapore.

Nevertheless, the public may still harbour misconceptions concerning the Community Policing Concept. Some say that it is no more than a variation of the Rakan Cop concept. Rakan Cop is a policing programme introduced by PDRM in Kuala Lumpur on August 9, 2005 to reduce the crime rate in the capital and other places across the country, whereas community policing is a expansion of that concept. The concept and guidelines for community policing are reinforced with the effort to raise co-operation and communication between society and the police. There are many ways to add to the effectiveness of community policing and neighbourliness. They include a greater willingness to engage the police, the role of police volunteers and the enhancement of the Rukun Tetangga sector.

Under the procedures of community policing, a police officer would be responsible for a specific sector. The officer on duty identifies himself to the residents as the Community Relations Officer. He makes his telephone number available so that he can be contacted easily. Meetings are held periodically between residents and the police to discuss problems, make suggestions and listen to the opinions of the residents. This is essential to obtain vital information from the public, especially in regard to ongoing investigations of the police. With each district Police Office forming its own Community Policing Unit, it is hoped that the experience and perception of society towards crime in their area would gradually change.

In Johor Bahru, for example, the crime rate has declined, while the perception of the local people towards the police has improved. This concept is the current approach towards replacing conventional policing. The active involvement of society in helping the police curb crime is pivotal to the concept of community policing. Residents can forward information to the police without fear, a move that is crucial in the eradication of crime. With the implementation of community policing by PDRM, members of the public have become aware that the eradication of crime does not fall on the shoulders of the police alone.

\section{Methodology}

This study adopts an investigative methodology that combines theory with case studies.

\section{Case Study}

A case study approach was adopted for this study. The compilation of data was made through literature search, interviews with representatives from the Town Planning Department and also from secondary sources, including journals, seminar papers and reports. Besides this, data were also collected through observations of 
Gated Community housing schemes in Johor Bahru.

\section{Discussion of Findings}

\section{Security Aspects in Gated Community Housing}

Residents in a Gated Community enjoy relatively tighter security as compared with those living in other types of housing schemes. Six principal elements in Gated Community Housing, viz., regulated entry, intercom system, security cameras (closed circuit television-CCTV), security guard patrol, 24 hour security control and guard-house (see Table 2).

Table 2

Security Aspects in Gated Community Housing

\begin{tabular}{|c|c|}
\hline Aspect & mponent/Justification \\
\hline $\begin{array}{l}\text { i. Boundary } \\
\text { fence }\end{array}$ & $\begin{array}{l}\text { Gated Community housing is designed with perimeter fencing and landscaping that restricts view from the outside. } \\
\text { The fence or wall restricts entry into the Gated Community and controls the incidence of crime within the community. } \\
\text { Entrances with boom barriers are popular in facilitating the screening of visitors to the Gated Community. Residents } \\
\text { are issued entry passes by the community or security management for the purpose of security control.Residents with } \\
\text { access passes that are appropriately electronically encoded have access into the Gated Community. Certain Gated } \\
\text { Communities control entry through the use of stickers for residents' cars or motorcycles. }\end{array}$ \\
\hline & ds. \\
\hline $\begin{array}{l}\text { iii. Intercom } \\
\text { system }\end{array}$ & $\begin{array}{l}\text { e intercom system is a means by which to regulate and prevent outsiders from entering the Gated Community. } \\
\text { ch housing unit is fitted with an intercom system connected to the guardhouse for the convenience of the residents. } \\
\text { e intercom system enables residents to communicate with the security guardhouse to validate their visitors and to } \\
\text { uest assistance in the case of emergencies, without having to go to the guardhouse. }\end{array}$ \\
\hline $\begin{array}{l}\text { iv. CCTV } \\
\text { system }\end{array}$ & $\begin{array}{l}\text { e CCTV system is installed to enhance the effectiveness of security control. The security guard needs only to view } \\
\text { ch entrance and exit in the housing area, as well as at other strategic locations to monitor and record persons } \\
\text { tering or exiting. This indirectly helps the police in identifying suspects in the event of any undesired incidents, }\end{array}$ \\
\hline $\begin{array}{l}\text { v. Security } \\
\text { guard } \\
\text { patrol }\end{array}$ & $\begin{array}{l}\text { Patrols in the Gated Community are still required even when intercom and CCTV facilities are installed. The security } \\
\text { guard on patrol sees for himself the situation in the actual surroundings. Security guards normally patrol the Gated } \\
\text { Community in shifts. Each patrol session may last } 3 \text { hours. The patrols are aimed at ensuring security within the } \\
\text { Gated Community. }\end{array}$ \\
\hline $\begin{array}{l}\text { vi. } 24 \text { hour } \\
\text { security }\end{array}$ & e security service operates 24 hours a day. Security guards normally work in shifts. The security guard usually \\
\hline
\end{tabular}

\section{Conclusion}

The concept of Gated Community housing in property development is considered one of the most effective measures to maintain personal safety in a residential area. Gated Communities that feature full-time security services reconcile with the aspirations of the Safe Township concept that is based on the tenet that "crime prevention is better than crime eradication”. This approach to crime prevention promulgates the safe environment as being the key to crime reduction.

\section{References}

Ainur Zaireen Zainudin. (2006). Keberkesanan Program Bandar Selamat Dari Persepsi Penduduk (Tesis Sarjana, Universiti Kebangsaan Malaysia).

Azlinor Sufian dan Ahmad Ibrahim. (2005). A legal perspective on gated communities in Malaysia. International Conference of The Asian Planning School Association. University Glasglow.

Clarke, P. (2004). Developing a gated community. Seminar Gated and Guarded Communities, April 17 2004, Hotel Istana in Kuala 
Lumpur.

Cozens, P. M., \& Plimmer, F. (2000). Crime and its relationship to environment (Editorial). Property Management, $18(2), 89-91$. Economic Planning Unit (EPU). (1999). Quest for a better quality of life. Malaysia quality of life report.

Ferrans, C. C. (1990). Quality of life: Conceptual issues. Seminars in Oncolody Nursing, 6, 248-254.

Grant, M., Ferrell, B. R., \& Sakurai, C. (1994). Defining the spiritul dimension of quality of life assessment in bone marrow transplant survivors. Oncolody Nursing Forum, 21(2), 376-388.

Jamaludin Mustaffa. (2007). Aspek Keselamatan Awam Dalam Pembentukan Bandar Selamat Di Malaysia (Buku Tesis Ph.D. Universiti Sains Malaysia).

Jeffrey, C. (1972). Crime prevention through environmental design. Beverly Hills: Sage.

Lynch, K. (1960). The image of the city. Cambridge: MIT Press.

Lynch, K. (1981). Good city form. Cambridge: MIT Press.

Maslow, A. (1954). Motivation and personality. New York: Harper \& Row.

Newman, O. (1972). Defensible space. New York: Macmillan.

Newman, O., \& Franck, K. A. (1980). Factors influencing crime and instability in urban housing developments. Washington, D.C.: National Institute of Justice.

Norazmin Adibah binti Othman. (2007). Kriteria Perancangan dalam Pembangunan Perumahan Komuniti Berpagar di Kawasan Dewan Bandaraya Kuala Lumpur (Buku Tesis Sarjana. Universiti Teknologi Malaysia, Skudai, Johor).

Paul Michael Cozens, Greg Saville, \& David Hillier. (2006). Crime prevention through environmental design (CPTED): A review and modern bibliography. Department of the Premier and Cabinet, Perth Australia.

Wan Rozali Wan Hussin. (2002). Kualiti Hidup Sosial Dan Proses Perbandaran Di Malaysia. Kertas Seminar. Bahagian Geografi Pusat Pengajian Pendidikan Jarak Jauh Universiti Sains Malaysia.

Wilson, J., \& Kelling, G. (1982). Broken windows: The police and neighbourhood safety. The Atlantic Monthly, March, 29-38. 